\title{
Clean India
}

\author{
Aparna Nayak \\ University of Idaho, Boise, USA \\ Email: naya6277@vandals.uidaho.edu
}

Received 22 June 2015; accepted 25 July 2015; published 28 July 2015

Copyright (C) 2015 by author and Scientific Research Publishing Inc.

This work is licensed under the Creative Commons Attribution International License (CC BY).

http://creativecommons.org/licenses/by/4.0/

(c) (i) Open Access

\begin{abstract}
Mahatma Gandhi was mindful of the poor position of Indian rural people at that time and he dreamt of a cleaner India, where he emphasized on cleanliness and sanitation as an intact function of surviving. President Pranab Mukherjee in his address to Parliament in June 2014, said, "For ensuring hygiene, waste management and sanitation across the nation a "Swachh Bharat Mission" will be established. This will be our tribute to Mahatma Gandhi on his $150^{\text {th }}$ birth anniversary to be celebrated in the year 2019". The Narendra Modi Government will shortly establish the "Swachh Bharat" movement to solve the sanitation problem in India, to solve the problem of waste management and make India a clean state, ensuring hygiene all across the nation. Emphasizing "Clean India" on August 15, 2014 in his Independence Day speech, the Prime Minister said that this trend is linked with the economic activity of the state. This missionary work for creating a clean India will be launched on October 2, 2014, the birth anniversary of Mahatma Gandhi with the objective of completing the mission in 2019 , the $150^{\text {th }}$ birth anniversary of the father of the country.
\end{abstract}

\section{Keywords}

Waste, Clean India, Developing Countries, Solid Waste, Waste Management

\section{Introduction}

Sustainability Revolution was beginning in 1960-1970 with an environmental movement, its emergence in 1980's and at full-fledged condition in 1990's. The Ecological awareness was first raised by American writer and naturalist Rachel Carson's and other environmentalist with the first earth day with attracted 20 million people and educated the people about the impact of industrial society on the environment.

Sustainability Revolution turned out as a diverse, worldwide, and multicultural and multi perspective revolution on the 3E's, by focusing in all of them simultaneously leads to positive change both within and among societies. Ecology/Environment, Economy/Employment, Equity/Equality, all these 3E's are important in Sustainability, as it gives us strategy to move from unsustainable practice to a global relationship with nature that reconfigures not only human relationship with the earth and its biological diversity but also the structure of values for 
integrating ecological and economic issues (Munier. N (2005) [1].

First, Ecology/Environment sustainability is important for the human existence which includes air, water, heating, cooling and food that is safe to eat. This existence on ecosystem will disturbed on ecological crisis like destruction of oceans by overfishing, forests by clear-cutting and fresh water by toxins and pollutants. Second, Economy/Employment sustainability is important for creating long term employment but not on the stakes of ecosystem. As said by Hawken, Amory and Hunter "natural capital, made up of resources, living systems and ecosystem services" it is important for economic development as the more conventionally recognized human, financial and manufactured form of capital. Third, Equity/Equality sustainability is important for community as a whole in terms of ecological and long term economic development. It tells the well-being of individual and large community is interdependent. There must be equitable distribution of resources for long term viability of the society.

However, nearly every human activity creates some kind of waste. As countries develop economically, socially, and technologically—industrializing, urbanizing, and expanding in population - waste generation increases. The problems associated with waste affect both developed and developing countries. Globally, we live in "throw-away" societies in which we consume packaged products that often do not last past a single use or even a year, and we discard as waste what we no longer want. This wasteful lifestyle seriously impacts the environment, public health, and produces social and economic problems. Waste disposal can have serious environmental impacts: landfills consume land space, and cause air, water and soil pollution-including the emission of greenhouse gases, while incineration results in emissions of dangerous air pollutants. Our consumptive and often wasteful behavior needs to be examined, and changed, so that we can live more sustainably.

In the developing country like India Waste management is always been a major problem. Faced with rapid population growth, disorganization of city governments, a lack of public awareness and limited funding for programs, cities have struggled for years to find a way to responsibly manage the country's ever-increasing amount of trash. The Central Public Health and Environmental Engineering Organization (CPHEEO) has estimated that waste generation in India could be as much as 1.3 pounds per person per day. That figure is relatively low, compared to the 4.6 pounds of waste generated per person per day in the US. However, as of July 2009, the US population was close to 307 million, whereas India's population was nearly four times greater, at 1.2 billion (Earth 911. Trash Planet: India, 2009) [2].

These statistics mean that India could be generating as much as 27 million more tons of waste than the US per year, although it has only one-third the land space when it comes to finding suitable locations for final disposal. India's rapid population growth only magnifies the problem. The urban population has grown at a rate of more than 20 percent each year since 1980 and is projected to reach a rate of more than 30 percent by 2015. Many argue that the country's poorly organized waste management scheme will continue to result in serious health problems and irreversible damage to the environment. Most agree that the government, industry and citizens need to work together to make major improvements (Singh. K. The CSR Journal) [3].

Under those circumstances, global population rose to 6.9 billion in 2010 and the majority of people live in developing countries (UN-HABITAT, 2006-2007) [4]. A major challenge is how to manage the ever-increasing waste generated, especially in developing countries already lacking a sufficient public service infrastructure to manage municipal waste, and where poverty and unplanned settlements lead to unmanaged waste. In this paper I will discuss the most popular movement now in India which is not only playing and serving at large scale in the history but also a great example for developing nations to move towards sustainability which is "Swachh Bharat Abhiyan or clean India". Clean India is a national campaign by the Government of India, covering 4041 statutory towns, to clean the streets, roads and infrastructure of the country.

\section{The Pledge for All}

PM Narendra Modi has urged each and every one to pledge the following as a part of the Swachh Bharat Abhiyan: (Clean India Journal, I Pledge) [5]

"I take this pledge that I will remain committed towards cleanliness and devote time for this. I will devote 100 hours per year - that is two hours per week — to voluntary work for cleanliness. I will neither litter nor let others litter. I will initiate the quest for cleanliness with myself, my family, my locality, my village and my work place. I believe that the countries of the world that appear clean are so because their citizens don't indulge in littering nor do they allow it to happen. 
With this firm belief, I will propagate the message of Swachh Bharat Mission in villages and towns. I will encourage 100 other persons to take this pledge which I am taking today. I will endeavor to make them devote their 100 hours for cleanliness. I am confident that every step I take towards cleanliness will help in making my country clean.”-Narendra Modi, Prime Minister, India.

\section{The Clean India Campaign}

The Prime Minister of India Mr. Narendra Modi launched this campaign officially on 2 October 2014 at Rajghat, New Delhi and he himself cleaned the road. About 3 million government employees, school and college students of India participated in this event and it is considered as India's biggest ever cleanliness drive. The modules of the programme are: a) Construction of individual sanitary latrines for households below the poverty line with subsidy (80\%) where demand exists. b) Conversion of dry latrines into low-cost sanitary latrines. c) Construction of exclusive village sanitary complexes for women providing facilities for hand pumping, bathing, sanitation and washing on a selective basis where there is not adequate land or space within houses and where village panchayats are willing to maintain the facilities. d) Setting up of sanitary marts. e) Total sanitation of villages through the construction of drains, soakage pits, solid and liquid waste disposal. f) Intensive campaign for awareness generation and health education to create a felt need for personal, household and environmental sanitation facilities (Clean India Journal. Creating Cleanliness) [6].

The Narendra Modi Government launched the "Swachh Bharat" movement to solve the sanitation problem and waste management in India by ensuring hygiene across the country. Emphasizing on "Clean India” in his 2014 Independence Day speech, PM Modi said that this movement is associated with the economic activity of the country. The prime objective of the mission is to create sanitation facilities for all. It aims to provide every rural family with a toilet by 2019 (Rukmini. S. October, 2014. The Hindu) [7].

Modi has directly linked the Clean India movement with the economic health of the nation. This mission, according to him, can contribute to GDP growth, provide a source of employment and reduce health costs, thereby connecting to an economic activity. Cleanliness is no doubt connected to the tourism and global interests of the country as a whole. It is time that India's top 50 tourist destinations displayed highest standard of hygiene and cleanliness so as to change the global perception (Phukan. S.R, September, 2014) [8].

Clean India can bring in more tourists, thereby increasing the revenue. He has appealed to the people to devote 100 hours every year to cleanliness. Not only had the sanitation programme, Modi also laid emphasis on solid waste management and waste water management. He has also directed that separate toilets for boys and girls should be provided in every school in the country by 15 August, 2015.

According to government data, in January 2015, 7.1 lakh individual household toilets have been built under this dream project. This number is considered the highest for any month since its launch in October 2014. 31.83 lakhs individual toilets have been built until January 2015. So far, Karnataka is the best performer by achieving $61 \%$ of the target while Punjab is the worst performer by achieving 5\% of the target (Sharma. Y. Feburary, 2015) [9].

With effect from 1 April 1999, the Government of India restructured the Comprehensive Rural Sanitation Programme and launched the Total Sanitation Campaign (TSC). To give a fillip to the Total Sanitation Campaign, effective June 2003 the government launched an incentive scheme in the form of an award for total sanitation coverage, maintenance of a clean environment and open defecation-free panchayat villages, blocks and districts called Nirmal Gram Puraskar. Effective 1 April 2012, the TSC was renamed to Nirmal Bharat Abhiyan (SBA). On 2 October 2014 the campaign was launched as Swachh Bharat Abhiyan (Coates. S; Dulk. D.C. November, 2014. Elsevier connect) [10].

This campaign aims to accomplish the vision of a "Clean India" by 2 October 2019, the $150^{\text {th }}$ birthday of Mahatma Gandhi. It is expected to cost over Rs. 62,000 crore (US \$9.7 billion). Fund sharing between the Central Government and the State Government and Urban Local Bodies (ULBs) is 75\%:25\% (90\%:10\% for North Eastern and special category states). The campaign has been described as "beyond politics" and "inspired by patriotism”.

\subsection{Swachh Bharat/Clean India Run}

On 2 October 2014 a Swachh Bharat Run was organized at the Rashtrapati Bhavan. As per the announcement from the Rashtrapati Bhavan around 1500 people participated and the event was flagged off by President Pranab 
Mukherjee. Participants in the run included officers and their families.

\subsection{Swachh Bharat/Clean India Apps}

To support the mission using mobile technologies Appdance sucks developers came up with ideas. The Times of India published an article on how "Desi companies beat Facebook in 'Swachh' apps race”. It seems like Facebook CEO Mark Zuckerberg may have reach out to help the government create a "Swachh Bharat" or "Clean India" app but local talents had already been ready with their apps and beat him. One of among these apps is "I Clean India-Swachh Bharat” on android play store, by a Delhi-based startup Social Cops. This app has an operational linkage with the Bangalore municipal corporation. These can then be used to invite Facebook friends or Twitter contacts through the app (Arora. K. October, 2014. Times of India) [11].

The Swachha Bharat campaign was launched by Prime Minister Narendra Modi on Gandhi Jayanti. Since then many eminent personalities like Salman Khan, Anil Ambani, and Omar Abdullah have taken up the task and many have posted pictures of themselves cleaning up their neighborhoods. (india.gov.in) [12].

\subsection{Real-Time Monitoring}

The toilets constructed under the Swachh Bharat Abhiyan will be monitor nationwide by government with a real-time monitoring system. This has already created an awareness among people by the government of India through a quite good advertisements. Moreover, this system will help government aims to attain a $100 \%$ open defecation free India by 2019.

The Indo Nepal Doctors Association has launched Swachh Bharat Nepal on 3 January 2015 after getting inspired from the Prime Minister of India. Swasth Bharat Nepal Abhiyan was launched at the Indo-Nepali border region of Sunauli-Belihiya, which is the entry to the birthplace of the Buddha, Lumbini, Nepal.

\section{Cleaning Market}

To create a favorable market dynamics even in the cleaning industry the best way is through innovations. Although the Indian cleaning market is growing, which will affects the innovations and trends internationally, aiming the specific necessities of this unique growing market. The $25^{\text {th }}$ ISSA Interclean show at Amsterdam attracts around 29,325 professionals visiting from about 130 countries and 696 companies exhibiting from across the globe. More than 184 products launched at the Show highlighted the important aspects of cleaning requirement and solution in given circumstances.

The most important aspects of international companies looking at this market are firstly, the overall growth in the country leading to rise in cleaning opportunities and secondly, the economic slowdown pushing Western countries to look at alternative growing markets like India, China and Russia. It was about $80 \%$ of the exhibitors were interested in either considering at entering/exploring the Indian market or have already apportioned distributors in India. The Indian market is flexible at the present time by giving priority to cleaning. With the time as the cleaning projects going to increase, the demand for general cleaning products, specific solutions and consumption volumes are definitely going to rise.

But the main question at the present time is that whether the Indian cleaning industry be able to encounter these requirements with the existing infrastructure and technology. Another question is whether the international community hurry to fill the gap. Is there any opportunity for India to witness technology transfer, increased distributorships, or direct international presence in the coming years? However, there are obvious challenges in the developing trend. The one among which is the price conscious Indian consumer market. Even though, considering the price challenge there are manufacturers from Germany, Spain and even the UK who have taken up the challenge and are redesigning/customizing products to fit the price factor. At the same time, there are manufacturers, from Italy, USA in particular, who are skeptical and cautious of their dealings in India owing to price mismatch.

On the other hand, the other challenges faced by the international market is a lack of awareness and knowledge about cleaning technology among the Indian consumers. In the present situation where cleaning is not count among the top main concern or is not exclusively budgeted by Indian companies. So, moving toward the latest cleaning technology and investment on cleaning is limited.

Nonetheless, the demand for cleaning over the past few years has been steady, the growth in the Indian clean- 
ing industry has been unpredictable. As a result of which Indian companies were not in the favor of international tie-ups introduced during this period. Keeping the dealings in suspension is also having a detrimental effect on manufacturers who are eagerly awaiting confirmation from prospective Indian companies. The companies are from France, UK, Denmark and Spain. USA and the UK, two of the biggest players in cleaning, that have been concentrating production and distribution to the local market, are now expanding operations not only to Europe but also to India, China and the Middle East.

The other involving tendencies in India are unfavorable to positive growth in the cleaning industry are eroding margins, unhealthy competition, thieving and others leading to a nasty circle of payment problem. Innovations in the cleaning industry have largely focused on providing solutions to suit local market. Internationally, major players are redesigning products to suit the specifics of Indian cleaning needs. The best part when concluding, despite challenges, the cleaning industry as a whole is looking at India as a potential market and taking intensive steps to grow. As more and more international companies steps into Indian market, the country is sprouting as a perfect platform for the cleaning business.

\section{Economy Depends on Cleanliness}

Undoubtedly, Indian tourism offers a wide array of unique travel destinations, services, medical aides, and education. Traditionally, India boasts of an ancient culture that left behind exquisite monuments and temples, archaeological sites and an heirloom of artefacts. India is also endowed with natural beauties and unique features right from the beaches to the majestic mountains and hill stations, from rainforests to scintillating deserts, from bird sanctuaries to natural reservoirs, - the list is endless. In spite of the beautifully conceptualized global advertising campaign about Incredible India, India still has a meagre $0.64 \%$ of the total tourist arrivals worldwide. It is evident that the culturally rich central theme "Atithi Devo Bhavah" coupled with historical and natural resources is unable to make the most of the opportunity created by the world tourism industry.

According to UNWTO, over the past six decades, tourism has experienced continued expansion and diversification, becoming one of the largest and fastest-growing economic sectors, with the receipts of International tourism worldwide reaching to US $\$ 1159$ billion in 2013. The business volume of tourism equals or even surpasses that of oil exports or automobiles. Tourism is a high potential industry the world over and there are several economies which are directly dependent on the tourism industry.

Tourism in China has hugely expanded over the last few decades, making China the fourth most visited country in the world with over 56 million (5.1\%) arrivals and a whopping business of a US \$52 billion. China's tourism strategy depicts a high sense of discipline and hygiene, and single-minded objective of a great tourists’ experience. Thailand is also amongst the top-10 tourism destination in the world. Thailand attributes its success to low unemployment rate ( $7^{\text {th }}$ lowest in the world), $90 \%$ of population above poverty line, relatively developed economy and obviously its unique balance of city and nature experiences. Singapore alone has managed to attract 15.6 million international tourists bringing in massive receipts of US \$18,953 Million in 2013. The critical success factor in Singapore Tourism is cleanliness, beautiful cityscape and tourist experiences, and visa policy. India on the other hand, despite its diversities and vast tourism resources, managed to receive only seven million tourists (0.64\%), which brought home US \$18,397 million in 2013. Even with this miniscule share of the world tourism industry, tourism generates $6.6 \%$ of India’s GDP and 32 million Indians are directly employed by this sector.

But, the India is lagging behind in one very important aspect called, cleanliness. Lack of adequate sanitation and food safety leads to cross contamination which causes severe diseases. The Centers for Disease Control and Prevention (CDC) reports that between $20 \%$ and 50\% of international travelers suffer from diarrhea, due to ingestion of contaminated (mostly fecal) food or water infected with E coli. India along with other developing nations is burdened with the stigma of causing diarrhea to travelers, which is ironically called "Delhi-belly".

India needs to develop the facilities by revamping public utilities and keeping them clean, focusing on safe food \& water, training cleaning staff and preserving the environment. This complex task needs to solve one more issue, which is creating a dignity and quality of life for the cleaning staff and their families. Training staff repeatedly on standards of cleaning \& hygiene and application of chemicals can be very instrumental in motivating and providing them dignity. At the face value, this job may appear unreasonably complex. However, it can be executed at a nominal cost by adopting a partnering approach, especially between the users and the vendors; for example, between 5-star hotels and manufacturers of commercial cleaning solutions. The latter can 
regularly train the cleaning and kitchen staff of hotels with the intention of sustainability and objective of attain ssessments can be utilized to highlight and encourage best performers and set new standards (Clean India: community led environment action network) [13].

\section{Conclusions}

Moreover, Prime Minister of India target of complete sanitation in the next five years is aiming to change situation and behavior of India. A significant investment in cleanliness, hygiene training, maintenance and human resource linked to Swach Bharat Abhiyan will certainly support the Incredible India Campaign. Not only this, it can be a direct influence on the medical tourism, increasing its scope even further. The days are not too far when we will send off tourists with fond memories of a cleaner and welcoming India, adorned with cultural heritage, aesthetic artefacts, rich flora \& fauna and natural scenic beauties. The PM has rightly asserted that Swachh Bharat Abhiyan should be a combined effort of both the Government as well as the people. Everybody is in the hope that the Swachh Bharat Mission does not become another Nirmal Bharat Abhiyan started by the previous Government in 1999 with the same mission but was far from a success.

Trash is closely connected to every environmental problem we face today, from climate change and habitat destruction to water pollution and chemical exposure. It's also intensely personal and impacts every decision in our daily lives, including everything from how much money we spend to how much weight we gain. The storage, collection, transportation, processing, recovery, and disposal of solid waste results into very difficult task for solid waste management. Only collection and transportation includes \$6 billion a year. Most solid waste is transported to dumps and landfills; the rest is incinerated. In 1970, studies on solid waste indicate, as many as 90 percent of the dumps and 75 percent of the municipal incinerators were considered inadequate, and were major polluters of air, land, and water.

After looking at this shocking and horrible truth about waste I have concluded that to change the country's trash addiction, we first have to address own trash problem. I had heard about people in other parts of the world living "trash free," which basically means sending nothing to the landfill-ever. I wondered if the same could be happen in developing nation, in a country where people produce more trash than anywhere else in the world. The best and amazing parts of following cleanliness lifestyle are really life changing and motivating for an individual. It gives you simple life, saves money, supports local business, eat healthier, preserve planet for future generations, more self-efficient, sustainability etc.

As an individual I would suggest everyone to follow the pollution prevention hierarchy and practice to stay as high as possible in the hierarchy. The best thing which can do and contribute towards reduction of solid waste is to reduce it first at its source which we can easily start from our home by following some zero waste technique. Everyone contributes to national and global pollution and this cannot solved by governments alone. For their policies to work effectively the actions of the individual are required. The collective action by individuals would reduce solid waste generation, water use, and energy use and results into whole reduction in Pollution around the globe.

Swachh Bharat Abhiyan should not be a mere re-branding exercise. There is no doubt about the fact that change begins at home. Every citizen of the country should take it upon himself to make this campaign a success rather than waiting for the government to do. Let us also hope that this can change the attitude of the people towards hygiene and be the change everyone wants to see.

\section{References}

[1] Munier, N. (2005) Road to a Better Future: Introduction to Sustainability.

[2] (2009) Earth 911. Trash Planet: India. http://www.earth911.com/earth-watch/trash-planet-india/

[3] Singh, K. How to Make Your Garbage Green in Two Easy Steps. The CSR Journal. http://thecsrjournal.in/how-to-make-your-garbage-green-in-two-easy-steps/

[4] The State of the World Cities Report. 2006-2007. https://sustainabledevelopment.un.org/content/documents/11292101 alt.pdf/

[5] Clean India Journal, I Pledge. http://www.cleanindiajournal.com/i-pledge/

[6] Phukan, S.R. (2014) Swachh Bharat Abhiyan: Making India Clean \& More. http://www.mapsofindia.com/my-india/society/swachh-bharat-abhiyan-making-india-clean-more 
[7] Sharma, Y. (2015) Swachh Bharat Abhiyaan: Government Builds 7.1 Lakh Toilets in January. http://articles.economictimes.indiatimes.com/2015-02-17/news/59232518_1_india-open-defecation-swachh-bharat-abh iyan-toilets

[8] Abhiyaan, S.B. Ek Kadam Swachhata Ki Ore. http://india.gov.in/spotlight/swachh-bharat-abhiyaan-ek-kadam-swachhata-ki-ore

[9] Clean India Journal, Creating Cleanliness. http://www.cleanindiajournal.com/creating-cleanliness/

[10] Rukmini, S. (2014) The Hindu. Modi Launches “My Clean India” Campaign. http://www.thehindu.com/news/national/modi-launches-my-clean-india-campaign/article6468047.ece

[11] Coates, S. and Dulk, D.C. (2014) Elsevier Connect. Making a Stink: @UNICEFIndia Seeks to End Open Defecation. http://www.elsevier.com/connect/unicef-india-campaigns-to-end-open-defecation

[12] Arora, K. (2014) Times of India. Desi Companies Beat Facebook in “Swach” App Race. http://timesofindia.indiatimes.com/tech/tech-news/Desi-companies-beat-Facebook-in-Swachh-apps-race/articleshow/4 4929578.cms

[13] Clean India. Community Led Environment Action Network. http://www.cleanindia.org/ 